\title{
ASEAN AT 46: SECURITY COMPETITION, SECURITY REGIME OR SECURITY COMMUNITY?
}

\author{
Er-Win Tan
}

\begin{abstract}
Since its founding, there has been significant debate over the extent to which the Association of Southeast Asian Nations (ASEAN) has succeeded in institutionalising reciprocal security cooperation in Southeast Asia. A review of the academic literature on the security dilemma, focussing on security regimes and security communities as sources of order in international politics, helps to frame a yardstick upon which the achievements of ASEAN may be assessed. In this regard, whilst ASEAN has not yet evolved into a security community, it may be argued that the association may be seen as a qualified success in promoting a security regime insofar as the norms of sovereignty are concerned. At the same time, however, the emergence of nontraditional security issues alongside the four new members of ASEAN highlight the need to expand the scope of the existing ASEAN security regime to encompass an expanded agenda for long-term security cooperation in the regime.
\end{abstract}

Keywords: Security Dilemma, security regime, security community, ASEAN

\section{INTRODUCTION}

With 46 years behind the Association of Southeast Asian Nations (ASEAN), there is significant debate over the extent to which this grouping has managed to promote norms of security cooperation in Southeast Asia. Critics of the association have dismissed ASEAN as a 'talk-shop' that has achieved little in concrete policymaking or in consolidating norms of restraint and security cooperation. Supporters of ASEAN, in contrast, have acknowledged that, although the association is far from perfect, an assessment of its success has to take into account the progress that it has achieved since its founding in 1967.

The author would take a middle position in assessing the extent to which ASEAN has successfully promoted norms of security cooperation in the region. In light of the extent to which ASEAN has managed to curb the prospect of large-scale conventional conflict since its founding, there are grounds to argue that the organisation has managed to promote a security regime insofar as traditional security issues are concerned. At the same time, however, the emergence of non-traditional security issues in Southeast Asia occurs at the same time that the association has taken on board four new members, namely Cambodia, Laos, Myanmar and Vietnam. These trends underline the urgency of further ASEAN efforts to promote long-term security cooperation in Southeast Asia. Given that ASEAN members do not show any sense of a shared identity, however, it is unlikely that an ASEAN security community will form an ideal diplomatic vehicle for the promotion of security cooperation for the 
foreseeable future. Rather, it may be argued that a security regime offers the best prospect for promoting security cooperation in ASEAN.

This argument will be presented in four parts, beginning with a brief examination of the academic literature on security regimes and security communities as theoretical approaches to promoting reciprocal norms of long-term security cooperation in international politics. This will be followed by an assessment of the extent to which ASEAN and the ASEAN Regional Forum (ARF) have promoted such norms of security cooperation, taking into account the geopolitical context of ASEAN' s founding in 1967. The third section of this chapter proceeds to highlight the emergence of non-traditional security issues in ASEAN and their potential impact on regional security, and how these reflect the continued shortcomings of security cooperation in ASEAN. The fourth section concludes this chapter by assessing the prospects for further promotion of long term security cooperation in ASEAN.

\section{SECURITY COMMUNITIES AND SECURITY REGIMES}

Set against the condition of anarchy in international politics, a significant range of approaches to exploring the possibility of security cooperation in international politics can be identified in the academic literature. Due to the constraints of space, I have chosen to focus on two such approaches, namely security regimes and security communities.

In acknowledging the possibility of long-term reciprocal security cooperation between states, Jervis argued that states could enter into security regimes for the purpose of facilitating long-term reciprocal security cooperation. ${ }^{1}$ Jervis defined a security regime as the "principles, rules, and norms that permit nations to be restrained in their behavior in the belief that others will reciprocate." ${ }^{2}$ In his article entitled "Security Regimes", Jervis contended that the cooperation entailed in a security regime is based on reciprocal acknowledgement of the legitimate security interests of others in the regime; it is also assumed that the process of security cooperation will continue over the long term. ${ }^{3}$ Within a security regime, states adopt restraint in their mutual interaction and observe norms of cooperation in their political and military postures in expectation of reciprocal restraint from other states. By enabling both sides to reach mutually acceptable limits on the extent of their competition for security, states could achieve a satisfactory level of long-term security for themselves without undermining the security of others. ${ }^{4}$ At the same time, however, Jervis himself argued that the concept of a security regime offers only a limited basis for long-term security competition. Jervis underlined the difficult conditions faced by states in seeking to establish a security regime. Security regimes cannot be formed when one or more members of a region believe that its security is best served by aggressive expansionism. Under such circumstances, the existence of incompatible security interests by states in the region prevents the formation of a long-term basis for reciprocal security cooperation. Similarly, Booth and Wheeler argue that the security cooperation envisaged by Jervis within a security regime is based on a narrow conception of security. Booth and Wheeler argued that such states are rational egoists driven by a static prioritisation on self-interest. ${ }^{5}$ Under such circumstances, the extent to which norms of security cooperation have been internalised is limited insofar as policymakers view the security regime as being useful for their own interests. Given that the interests of states may change, the value 
that states place on a security regime may prove difficult to sustain over the long run. Thus, for instance, the security regime embodied in the Concert of Europe began to unravel during the 1820s, and failed to prevent the Crimean War between Britain and Russia. $^{6}$

The possibility of military and diplomatic self-restraint as a basis for building a long-term basis for reciprocal security cooperation in mitigating the security dilemma was further explored by Glaser, who argued that under certain circumstances, defensive states can signal their peaceful intent towards one another. Glaser argued that security-seeking states are likely to consider what kinds of weaponry are most effective in enhancing deterrence, and if deterrence fails, defence. Such states can also ask themselves what military capabilities are less threatening to the defences of other states. ${ }^{7}$ Defensive states can thus agree to measures that limit or eliminate offensive weapons and thus sacrifice their ability to attack one another, for instance, by maintaining obsolete weapons that limit their ability to attack other states, instead of undertaking military upgrades that would confer on them offensive power projection capabilities. $^{8}$

The narrowly defined basis for security cooperation outlined in security regime theory is distinguished from the concept of a regional security community, a concept outlined by Deutsch and his collaborators in Political Community and the North Atlantic Area: International Organization in the Light of Historical Experience. Deutsch and his collaborators defined a security community as "a group [of states]... which has become "integrated", with a "sense of community". ${ }^{9}$ Such a community is based on a shared sense of identity governed by shared norms and expectations of peaceful conduct. Thus, although disputes and problems may exist between members of a security community, they have a shared belief "that common social problems must and can be resolved by processes of 'peaceful change'." extent of security cooperation goes further than that under a security regime. As noted earlier, the members of a security regime have agreed to norms of long-term, reciprocal security cooperation as rational egoists seeking to promote their selfinterests. In contrast, the members of a security community have a shared identity of themselves as belonging to a community based on shared values. Although rivalry and disputes may occur in a security community, its members are not only expected to exercise restraint in their dealings with one another, but they are also expected to reject the use of force as a means of resolving their disputes. ${ }^{11}$

\section{ASEAN: A QUALIFIED SUCCESS IN SECURITY COOPERATION?}

It may be argued that ASEAN may be seen as a qualified success as a security regime insofar as mitigating 'traditional' security issues such as interstate conflict is concerned. This is particularly the case in light of the geopolitical context of ASEAN' $\mathrm{s}$ founding. At the same time, however, it is necessary to acknowledge that ASEAN has its share of limitations in promoting security cooperation in the Asia Pacific. These limitations to ASEAN's track record are particularly pertinent in light of the four new members of the organisation (Cambodia, Laos, Myanmar and Vietnam).

Critics of ASEAN have been quick to criticise the organisation as a 'talking shop' that has achieved little in actual policymaking. Lim, for instance, has criticised ASEAN for its inability to present a united policy front in response to China's 
territorial claims in the South China Sea. Lim argues that ASEAN members have been driven by short-term self-interest, rather than any notion of long-term reciprocal security cooperation. ${ }^{12}$ Other critics have argued that, as a result of ASEAN's lack of a strong policymaking mechanism, it is unlikely that the grouping will be able to develop into a credible multilateral organisation. As The Economist noted in response to $14^{\text {th }}$ ASEAN Summit in March 2009, ASEAN leaders "made a lot of noise about deepening the integration of their economies ... but they failed to come up with any concrete measures." 13 Furthermore, The Economist noted that as a result of the grouping's 'ASEAN Way' ethos of non-interference in the domestic affairs of its members, it is unlikely that ASEAN will emerge as a credible organisation for the foreseeable future insofar as human rights are concerned. Although the ASEAN $14^{\text {th }}$ Summit declared that "the establishment of the ASEAN Human Rights Body... would be one of the most important undertakings to make ASEAN a genuinely peopleoriented community"14, ASEAN leaders have refrained from putting significant pressure on the Myanmar leadership over its human rights record. ${ }^{15}$

This has been reflected in ASEAN's responses to Myanmar's human rights record, since the latter's admission to the organisation in 1997. As Haacke argued, ASEAN members have been less than forceful in pushing for concrete action to be taken in response to the Myanmar's continuing suppression of pro-democracy activists during the second half of 2007. Although ASEAN members criticised the Myanmar government's use of violence, there was significant opposition to the adoption of United Nations sanctions against Myanmar. ${ }^{16}$ In a similar vein, Collins noted that ASEAN was reluctant to criticise Indonesia's suppression of independence activists in East Timor to avoid antagonising Jakarta. ${ }^{17}$ Other critics have argued that there is an intra-ASEAN arms race that reflects the long-term incompatibility of security interests in the region. Given the maritime layout of Southeast Asia's geography, it is notable that several ASEAN states have acquired significant upgrades to their air and naval capabilities. For instance, in spite of the 1997 Asian Financial Crisis, Malaysia and Singapore have acquired advanced main battle tanks, multiple rocket launchers, advanced fighter aircraft, submarines and frigates, whilst Thailand purchased an aircraft carrier. Given that the defence capabilities of Southeast Asian states had previously focussed on littoral maritime defence, these arms acquisitions, by conferring blue water power projection, have given rise to concerns that the Southeast Asian region will be the setting of a $21^{\text {st }}$ century air and naval arms race. ${ }^{18}$

The aforementioned perspectives suggest that ASEAN's record in promoting security cooperation in Southeast Asia falls short in certain respects. At the same time, however, it is also necessary to take the geopolitical context of ASEAN's founding into account. At the time of ASEAN's founding in 1967, its focus was on hedging against conventional conflict whilst containing communism and promoting economic development. ${ }^{19}$ These strategic priorities were particularly significant given the security concerns faced by ASEAN at its founding. ${ }^{20}$ Furthermore, policymaking during the 1960s was dominated by the Domino Theory, which postulated that if the non-communist governments of Southeast Asia were defeated by communist insurgency, this would provide other Marxist revolutionary organisations in the AsiaPacific region with increased political momentum. ${ }^{21}$ Moreover, the frequency of conflict in Southeast Asia during the 1950s and 1960s should be acknowledged. The Communist insurgency in Malaya and Thailand, and the Indonesian Konfrontasi, were recent memories for the founding members of ASEAN, the Vietnam War was at its 
height, and US commitment to the war effort in Indo-China was faltering due to increasing domestic dissent. ${ }^{22}$

Set against this background, ASEAN's record, although not perfect, suggests that the organisation has several notable achievements to its credit. A closer examination of the overall military postures and arms acquisitions of the founding members of ASEAN suggests that the claims of a 'Southeast Asian arms race' have been overblown. Although several notable arms acquisitions by ASEAN members have taken place over the last two decades, these do not necessarily point to an arms race. Rather, as Bull noted in his definition of an arms race: ${ }^{23}$

...the existence of armaments, and of sovereign powers commanding them and willing to use them, is a feature of international society, whether arms races are in progress or not... all international experience has been accompanied by the existence of armaments, the experience of peace as much as the experience of war.

In other words, what appears to be an action-reaction cycle of increasing arms acquisitions does not necessarily reflect an arms race. States may acquire more armaments as part of routine military modernisation, or in the case of newly independent states, to affirm their sovereignty whilst hedging against the possibility of a future external security threat. An arms race thus involves more than an actionreaction cycle of increasing weapons acquisitions by states. Rather, as Gray argued, in an arms race: ${ }^{24}$

[T]here should be two or more parties perceiving themselves to be in an adversary relationship, who are increasing or improving their armaments at a rapid rate and structuring their respective military postures with a general attention to the past, current, and anticipated military and political behaviour of the other parties. (emphasis in the original)

The patterns of arms acquisitions of Southeast Asian states do not fit this description of an arms race. Although the Southeast Asian region has seen the introduction of new armaments, these have not taken place on the scale or pace of an arms race as defined by Gray. It may be argued that various media agencies have exaggerated the impact of Southeast Asian arms acquisitions on regional security. ${ }^{25}$ Indonesia, for instance, has air and naval forces that amount to 16 elderly frigates, two submarines, six SU-27s, two SU-30s and 10 F-16s, a surprisingly small force to cover an archipelagic state of 1,904,569 square kilometres, let alone project military force overseas. ${ }^{26}$ Similarly, although Thailand's acquisition of an aircraft carrier has been cited as evidence of a Southeast Asian arms race, the HTMS Chakri Naruebet's complement of six sub-sonic Harrier II ground-attack aircraft is not a particularly strong force for blue-water power projection.

A somewhat stronger case to suggest that there is a Southeast Asian arms race concerns the relationship between Malaysia and Singapore, given their acquisition of significant numbers of modern weaponry. Thus, for instance, Singapore's acquisition of Leopard II main battle tanks and AH-64 Apache attack helicopters has been cited 
as a response to Malaysia's purchase of PT-91 main battle tanks. ${ }^{27}$ Furthermore, since the mid-1990s, both states have purchased significant numbers of modern fighter aircraft as well as submarines and frigates. ${ }^{28}$ Nonetheless, the notion of an arms race between Malaysia and Singapore can be challenged with an examination of the overall force posture and arms acquisitions of both countries. ${ }^{29}$ The number of main battle tanks acquired by both sides (Malaysia has acquired 48 PT-91s; Singapore, 96 Leopard IIs) would be enough to equip an armoured brigade at the very most, and are not particularly large for the purpose of projecting military power overseas. As Richard Simpkin argued, for the purpose of an offensive ground campaign, the attacking side should enjoy a three to one numerical superiority over the defender. ${ }^{30}$ By way of comparison, a typical armoured division - long considered the core component for an offensive ground war - has a complement of two to three hundred main battle tanks. ${ }^{31}$ Although the Singapore Army operates some 350 AMX-13 light tanks, ${ }^{32}$ these do not constitute an effective basis for an offensive campaign due to antiquated design and light armament of the AMX-13. ${ }^{33}$ If anything, it is possible that Singapore has delayed upgrades to its tank units in order to assure Malaysia of Singapore's defensive intentions. ${ }^{34}$ Moreover, it is also notable that Malaysia and Indonesia have not countered Singapore's acquisition of Leopard 2 tanks with acquisition of a comparable number of main battle tanks or anti-tank weapons systems. Similarly, although media attention has centred on the acquisition of advanced fighter aircraft (F/A18s, MIG29s and SU30s by Malaysia, F-15Es and F16s by Singapore), these force acquisitions are not consistent with the development of the airpower projection capabilities necessary for offensive military campaigns; rather, it is notable that Singapore has continued to operate large numbers of the elderly F-5 fighters, and retired the A-4 bombers only in 2005. Given that the F-5s and A-4s were designed in the 1950s (hence limiting their operational effectiveness in the $21^{\text {st }}$ century), it may be seen as an effort through which Singapore was willing to signal its defensive intentions whilst maintaining sufficient military capability for self-defence.

Seen in this light, rather than reflecting a fast-paced 'action-and-reaction' cycle of arms racing, such restraint in military modernisation in Southeast Asia reflects Glaser's argument that defensive states can signal their peaceful intentions to other states in order to mitigate the security dilemma by deliberately foregoing offensive military capabilities. ${ }^{35}$ Rather, such arms acquisitions may be seen as routine military modernisation in affirming the sovereignty of the post-colonial states of Southeast Asia. Such a perspective is supported by the fact that all ten members of ASEAN experienced gunboat diplomacy, invasion and Cold War politicking by foreign powers for much of their recent history, and all but Thailand were colonised by foreign powers. ${ }^{36}$ Furthermore, the supposed military protection offered by the European colonial powers (and the United States in the Philippines) counted for naught during World War Two when Japan swiftly occupied Southeast Asia. ${ }^{37}$ As a result of this historical background of conquest by external powers (and the resulting policies of the occupying powers), Southeast Asian states constantly perceive a need to constantly hedge against the possibility of external security threats. ${ }^{38}$ At the same time, it is notable that such hedging has involved limited acquisitions of modern weaponry that restrain the offensive application of their force postures, thereby challenging the notion of a Southeast Asian arms race. Moreover, given that Malaysia and Singapore form part of a collective security system (the Five Power Defence Arrangement, or FPDA), the prospect of conflict between Malaysia and Singapore is very low. $^{39}$ 
Further evidence that points to the emergence of an emerging security regime in ASEAN is reflected by the association's progress in promoting as well as accepting norms of diplomatic restraint and reciprocal security cooperation since 1967. In spite of the intra-ASEAN tensions and territorial rivalry of the 1960s, the organization has progressively moved towards an increasing acceptance of a shared code of conduct that reflects recognition of common interests and expectations of long-term reciprocal security cooperation. As early as 1971, and recognising that the economic development of the Southeast Asian region depended on foreign investors' confidence in regional stability, ASEAN leaders issued the declaration that ASEAN was to be a Zone of Peace, Freedom and Neutrality (ZOPFAN). The latter recognised "the right of every state... to lead its national existence free from outside interference in its internal affairs' and ASEAN members' common interest in 'economic and social stability... [and] their peaceful and progressive national development." further recognised in 1976 with the signing of the Treaty of Amity and Cooperation (TAC) that declared ASEAN's commitment to the "[s]ettlement of differences or disputes by peaceful means" and the "[r]enunciation of the threat or use of force." Furthermore, the organisation's diplomatic initiatives following the end of the Cold War similarly reflected expectations of long-term reciprocal security cooperation. ASEAN is a nuclear weapons free zone, and acceptance of the Southeast Asian Nuclear Weapons Free Zone Treaty of 1995 is considered a prerequisite for ASEAN membership. ${ }^{42}$ In establishing the ASEAN Regional Forum (ARF) as a basis for dialogue and confidence-building in Southeast Asia, the First ARF Chairman's Statement called for the forum to "foster constructive dialogue and consultation on political and security issues of common interest and concern", and thus "make significant contributions to efforts towards confidence-building and preventive diplomacy in the Asia-Pacific region.,

Although ASEAN's detractors contend that these statements reflect the association's status as a diplomatic 'talk shop', there are grounds to challenge this assessment of ASEAN. As Katsumata argued, an assessment of ASEAN's success has to take into account the strategic priorities of ASEAN at its founding. ${ }^{44}$ Given thethen dominant fears that Indonesia would attempt to impose regional and ideological hegemony on Southeast Asia, it is notable that ASEAN succeeded in bringing Indonesia into a more cooperative relationship with its Southeast Asian neighbours. By providing Jakarta with a channel for Indonesian interests to be aired, ASEAN effectively 'tamed' the Indonesian Government away from the nationalistic assertiveness of the Konfrontasi era. ${ }^{45}$ Furthermore, by giving Indonesia a stake in diplomatic influence in Southeast Asia, Jakarta's participation in ASEAN led to the Suharto Administration's increasing recognition that the use of force and confrontation to achieve regional hegemony was not in Indonesia's interests. ${ }^{46}$ This was reflected in a more moderate Indonesian foreign policy after 1967, as illustrated by the Suharto Government's restrained response to the Singapore Government's execution in 1968 of two Indonesian saboteurs implicated in the 1965 bombing of MacDonald House. Despite nationalist anger in Indonesia and calls for political and military retaliation, Suharto appealed for calm and did not go further than attempts to increase economic competition against Singapore. As Anwar argued, "although Indonesia was unhappy with Singapore... the Indonesia Government did not want to do anything which could jeopardize the very existence of ASEAN."47 Clearly, the Indonesian Government saw the norms of restraint embodied as ASEAN as being beneficial to Indonesia's long-term political and security interests. 
Furthermore, in spite of the territorial rivalry and disputes between the founding members of ASEAN during the 1960s, it is notable that none of these issues resulted in armed conflict. As Acharya noted, the founding members of ASEAN have not gone to war against one another since the founding of the organisation of $1967 .{ }^{48}$ Rather, Singapore's dispute with Malaysia over Pedra Branca/Pulau Batu Puteh, for instance, was resolved in an arbitration court, as was the territorial dispute between Malaysia and Indonesia over Pulau Sipadan and Pulau Ligitan. Seen in this light, more than a few critics of ASEAN have acknowledged the organisation's early successes in fostering security cooperation in Southeast Asia. Thus, for instance, in spite of her criticisms of ASEAN, Lim acknowledged that ASEAN was "a brilliant success in achieving its initial aim to nurture regional security by bringing Indonesia into a co-operative security relationship." 49

This is not to say that conflict in Southeast Asia is no longer a possibility, particularly with regards to the four new members of ASEAN. Rather, as reflected in the ongoing Thai-Cambodian dispute over border demarcation around the Prear Vihear temple complex, relations amongst ASEAN members have not fully developed to the extent that war is no longer a possibility. As a result of past centuries of mutual antagonism and national pride, both countries have, on several occasions, found themselves in a 'war of words' over their mutual border. This has led to escalating border skirmishes between the armies of Thailand and Cambodia, with casualties on both sides. ${ }^{50}$ More recently, Cambodia has recently appointed the controversial former Thai Prime Minister, Thaksin Shinawatra, as an economic advisor to Phnom Penh. ${ }^{51}$ Given Thaksin's unpopularity with the current Thai Government following allegations of corruption, Cambodia's actions have led to Bangkok retaliating by recalling its ambassador from Phnom Penh. ${ }^{52}$

Moreover, as an organisation, ASEAN has rarely been able to adopt a united front in addressing security issues arising from the policies of strong external powers. As early as its founding years, ASEAN members were divided in formulating a common security policy in response to communist expansion into Southeast Asia. Because of their perception of Soviet-backed Vietnam as the primary threat, Singapore and Thailand hedged their security by engaging the US in the region. In contrast, Malaysia and Indonesia saw China as the bigger threat to security in Southeast Asia. ${ }^{53}$ This lack of unity in forging a basis for formulating a common security policy has continued in the post Cold War era. Lim has noted that, in spite of China's reluctance to renounce its territorial claims to the Spratly Islands, ASEAN members remain unable to present a united policy response to Beijing. After the US military withdrawal from the Philippines at the insistence of Manila, for instance, ASEAN did little to support the Philippines against Chinese claims to Mischief Reef. Furthermore, as Lim argued, in spite of the ARF's attempts to engage Beijing, the Chinese Government has consistently shown little interest in clearly delineating the extent of its claims to the South China Sea. ${ }^{54}$

These perspectives suggest that a security regime has emerged insofar as the " traditional' security concerns of the founding members of ASEAN are concerned. Claims of an 'ASEAN arms race' are directly challenged by overall force postures that reflect a significant level of diplomatic restraint by ASEAN members. Even where significant arms acquisitions have taken place in the region, such as Singapore' $\mathrm{s}$, these have been accompanied by other actions that point to diplomatic restraint and 
recognition of the security concerns of Malaysia and Indonesia. Even whilst upgrading its military, Singapore has continued to retain significant quantities of 1960s-era armaments that would be of limited effectiveness in an offensive campaign. Furthermore, the diplomatic postures of the founding members of ASEAN reflect a level of restraint that would have been difficult to imagine during the turbulent 1960s that preceded the founding of ASEAN. Set against the backdrop of the Sukarno Government's policy of Konfrontasi, Indonesia's active involvement in the ASEAN Regional Forum and the ASEAN Plus Three arrangements reflects Jakarta's acknowledgement of the benefits of participation and security cooperation in the Southeast Asian grouping. In so doing, ASEAN has functioned as a channel for Indonesian influence that would otherwise emerge in the form of a nationalistic foreign policy similar to that of Sukarno. ${ }^{55}$

At the same time, however, there are grounds that the organisation has not developed into the 'nascent security community' as claimed by Acharya. ${ }^{56}$ Although Acharya has claimed that bilateral resolution of members' disputes and the principle of non-intervention in one another's internal matters indicates the emergence of a collective identity of ASEAN as a community, this perspective is not supported by an empirical record that suggests that intra-ASEAN cooperation has been driven by selfinterest rather than a collective ASEAN identification of itself as a community. Episodes such as the ongoing border tensions between Thailand and Cambodia and the spill-over effects of the domestic unrest in Myanmar suggest that the four newer members of ASEAN have yet to embrace the norms embodied in a security regime. Moreover, as demonstrated by China's continued threats of force (which have on some occasions resulted in actual clashes) in staking its territorial claims to the South China Sea, ${ }^{57}$ the ASEAN Plus Three arrangement has not yet developed into a security community. Rather, the threat of conflict over scarce resources in the South China Sea remains a distinct possibility, thereby suggesting that the region's identity has not developed to the extent that the war as an instrument of policy has been renounced.

\section{A NON-TRADITIONAL SECURITY AGENDA FOR ASEAN?}

This assessment of ASEAN's track record in promoting regional security cooperation comes at a time when the region is facing additional challenges in promoting norms of security cooperation, in particular, non-traditional security issues. During much of the Cold War, security was conceptualised as the domain of the state, and calculated in material factors such as armaments levels. In recent decades, however, scholars have increasingly argued in favour of an expanded view of security. This was reflected in Buzan's 1991 work, People, States and Fear: An Agenda for International Security Studies in the Post-Cold War Era. Buzan argued that it was necessary to adopt a broader understanding of security, one that incorporated non-traditional approaches to security that acknowledged the importance of sub-state actors. ${ }^{58}$ Since Buzan's seminal work, further scholarship has highlighted other emerging issues in international politics that arguably reflect the growing importance of non-traditional security issues on the international agenda. ${ }^{59}$ There has, for instance, been growing concern over the possibility of conflicts breaking out over increasingly scarce resources such as water and fishing grounds. ${ }^{60}$ Internal conflicts, civil wars and political repression have led to increasing refugee flows across state boundaries. The increase in maritime piracy in various parts of the world has affected commercial 
shipping lanes. ${ }^{61}$ Since September 11, there are growing concerns over the prospective threat posed by transnational terrorist networks. These security concerns point to an increasing shift from the nation-state to sub-state actors as referent objects of security. ${ }^{62}$

Moreover, the increasing impact of these non-traditional security issues on the interests of ASEAN is significant. By the very transnational nature of these emerging security issues, there is a likelihood of spill-over effects that concern the security of ASEAN members. It is notable that, in the context of ASEAN, many of the spill-over effects of these non-traditional security issues occur along existing fault-lines resulting from past legacies of mutual antagonism and nationalistic pride. This is of particular concern given that ASEAN's four new member states have not internalised expectations of long-term reciprocal security cooperation and diplomatic restraint to the same extent as the founding members of ASEAN. As reflected in the CambodianThai sovereignty dispute and border skirmishes over the Prear Vihear Temple Complex, a sense of an ASEAN community has not been embraced by the four new members of ASEAN, never mind a security regime that acknowledges common interests in long-term security cooperation.

The convergence of non-traditional security issues in Southeast Asia and the continued lack of institutionalised constraints on rivalry involving the four new members of ASEAN point to a need for the association to adopt a non-traditional security agenda. When the spill-over effects of non-traditional security issues occur in border areas between states with a past history of mutual antagonism and an absence of norms against the use of force, it is possible that the combined effect of these factors may be to cause tensions to escalate to the point of armed conflict. Thus, for instance, the competition for scarce water resources may have the potential to exacerbate existing tensions and antagonisms in Southeast Asia. Although media attention has highlighted the possibility of conflict between Malaysia and Singapore over scarce water resources, this is unlikely, given their high economic interdependence and, as mentioned earlier, the mutual restraint shown by both sides in resolving their various disputes. Of more concern, however, is the competition for scarce water resources in the Mekong River Basin which may exacerbate existing tensions and antagonisms between Thailand and the four new ASEAN members, all of which (together with China) share the Mekong River Basin. Although Dupont has argued that "there is no compelling evidence that environmental problems have been the primary cause of any major... inter-state conflict" (emphasis added) in Southeast Asia $^{63}$, it may be argued that such competition for scarce resources may exacerbate existing inter-state tensions, particularly if a given region lacks norms of restraint.

This is reflected by relations between Thailand and Cambodia, where their past history of wars, invasion and counter-invasion goes back several centuries, leaving behind a significant legacy of mutual antagonism that remains a salient point of conflict. Although conflict has not yet resulted from competition over diminishing water resources in the Mekong River Basin, this may occur in the foreseeable future given plans to harness hydroelectric energy. It is notable that Chinese efforts to harness the upper basin of the Mekong in Yunnan province have already led to falling water levels in the Indo-China branches of the Mekong. Furthermore, it is notable that three of Southeast Asia's militarily strongest states - Thailand, Myanmar and Vietnam - shared the Mekong River Basin, along with the People's Republic of China. 
Similarly, the Myanmar's crackdown on ethnic minorities has led to the flow of refugees across the border into Thailand. This problem is further compounded by the Myanmar government's alleged collusion in drug-trafficking with Wa ethnic minorities. The convergence of these non-traditional security issues have in turn led to cross-border raids and skirmishes, as reflected in February 2001 when Myanmar's forces took over a Thai border post. ${ }^{64}$

In seeking a response to this emerging range of non-traditional security concerns, statements by ASEAN officials increasingly reflect acknowledgement of the possibility of a security community in ASEAN based on comprehensive security. The ASEAN Regional Forum Inter-Sessional Support Group on Confidence Building Measures and Preventive Diplomacy in Singapore in October 2008, for instance, recognized that "nontraditional security issues such as climate change, food and energy security, terrorism, nuclear proliferation, and natural disasters continued to pose serious threats to regional security." ${ }^{, 65}$ Set against these challenges, the entry into force of the ASEAN Charter in December 2008 sought an 'ASEAN Community by 2015' that could be seen as a "genuinely people-oriented community" (thereby recognizing the growing importance of human security). More recent diplomatic statements by ASEAN policymakers further reflect the organisation's efforts to promote an institutionalized basis for promoting long-term security cooperation. At the Annual ASEAN Summit in October 2009, the organization launched its Intergovernmental Commission on Human Rights, seeking "progressive social development and justice, the full realisation of human dignity and the attainment of a higher quality of life for ASEAN peoples". The Intergovernmental Commission also envisaged that "ASEAN cooperation on human rights will continue to evolve and develop [into] the overarching institution responsible for the promotion and protection of human rights in ASEAN."

Although these statements suggest a level of institutionalized cooperation that would point to the emergence of a shared ASEAN identity of itself as a security community, this perspective is challenged by the continued sway of the ASEAN Way. As Desker argued, "Myanmar's continuing presence in ASEAN's chambers ensures that the traditional emphasis on noninterference and the sovereignty of states will be upheld by ASEAN." ${ }^{68}$ Such a perspective suggests that a security community based on the notion of human security is an unlikely outcome for the foreseeable future. Furthermore, given that the policies of ASEAN members continue to reflect a statecentric perspective of sovereignty and security, it is likely that a security community based on concepts such as human security remains unlikely for the foreseeable future. $^{69}$

In spite of this somewhat pessimistic assessment of the prospects for an ASEAN security community, there are nonetheless grounds to argue that long-term diplomatic and security cooperation is possible. As noted earlier, it may be argued that diplomatic and military restraint amongst the founding members of ASEAN reflects an acceptance of norms that frown on the use of force against fellow ASEAN members. This has led to a certain amount of stability between Malaysia, Singapore, Thailand, Indonesia, the Philippines and Brunei. Thus, in spite of episodes such as the sovereignty disputes over Pedra Branca/Pulau Batu Puteh and Pulau Sipadan and Ligitan, the likelihood of actual armed conflict resulting from these disputes was small. Furthermore, it is notable that these instances of intra-ASEAN security 
cooperation have taken place on the basis of common interests over security, rather than as a result of an identification of ASEAN as a security community. In other words, although ASEAN has not evolved into a nascent security community as argued by Acharya, it may be argued that there a security regime has emerged amongst the founding members of ASEAN, thus pointing to the organization's qualified success in promoting regional security and diplomatic cooperation.

Seen in this light, it may be argued that a security regime based on selfinterested cooperation amongst rational egoists offers the best prospect for ASEAN to address emerging non-traditional security issues. Given the continuing lack of an ASEAN identity (particularly when the four new members of ASEAN are taken into account), an ASEAN security community is not a plausible prospect for the foreseeable future. Furthermore, as Katsumata argued, given that social and economic development remains the priority of many ASEAN members, pressure for an integrated ASEAN that is involved in the domestic policies of its members is likely to prove premature, especially when seen from the perspectives of the four new members of ASEAN. In light of the latter states' recent unhappy experiences with colonialism and war, undue ASEAN involvement in their internal affairs is likely to lead to a backlash and increased suspicion of ASEAN's apparent infringement of their sovereignty. ${ }^{70}$ Such developments may in turn lead to their shunning of ASEAN, thereby reducing the diplomatic avenues through which norms of long-term cooperation can be promoted among the four new members of ASEAN. Such an outcome would represent the worst of both worlds - not only would key regional issues remain unresolved, but long-term efforts at promoting engagement would be complicated by the absence or non-cooperation of the four new members of ASEAN as a result of their fears of alleged 'meddling' by ASEAN.

A security regime, in contrast, may offer a stronger prospect for promoting ASEAN long-term reciprocal security cooperation in addressing emerging nontraditional security concerns in Southeast Asia. As security regimes are based on the notion of long-term cooperation arising from self-interest, such an arrangement would allow ASEAN members to acknowledge their mutual interests in addressing nontraditional security issues. Furthermore, given that such cooperation takes place between rational egoists, it would allow ASEAN members to ensure that such a level of security cooperation does not infringe on their sovereignty, thus maintaining the principle of the 'ASEAN Way'. Hensengerth, for instance, noted that the Mekong River Commission (MRC) proved to be more effective than the Quadripartite Economic Cooperation (QEC) in balancing between environmental protection, economic development, and the sharing of the Mekong River's resources. Although the MRC (comprising of Thailand, Cambodia, Vietnam and Laos) prioritised its members' economic interests, foreign funding for dam construction was hedged on local consultation to ensure that environmental protection would be simultaneously observed. ${ }^{71}$ In contrast, the Quadripartite Economic Cooperation (QEC) initiative, involving Laos, Thailand, Myanmar and China, collapsed because it pushed too strongly for consensus, in the process leading to Thailand and China asserting their national interests against each other. ${ }^{72}$

\section{CONCLUSION}


Even whilst suggesting that a security regime offers the strongest prospect for promoting an ASEAN policy response to non-traditional security, however, it is also necessary to acknowledge three major limitations. First, as an ASEAN security regime would be based on adherence to the ASEAN Way and non-interference in its members' internal affairs, it is likely that many key aspects of non-traditional security will not be addressed. As Jervis noted, a security regime would not be possible when its potential members have different, and irreconcilable, conceptions of the word " security'. ${ }^{73}$ This would particularly be the case where the interests of ASEAN are incompatible to the extent that compromise cannot be reached. It is unlikely that a human security regime will gain much headway amongst certain ASEAN members, in particular Myanmar, where government repression of pro-democracy activists has continued in spite of ASEAN pressure. ${ }^{74}$ Under such circumstances, ASEAN members' different conceptions of security will prevent the emergence of a long-term basis for the promotion of human security. A second limitation to an ASEAN security regime also arises from the ASEAN Way. Given ASEAN's tendency to prioritise consensus and dialogue over action, its members' opposition to ASEAN policies may stymie attempts to formulate a common ASEAN security policy. Moreover, as a forum for dialogue rather than policymaking, the difficulty of implementing ASEAN security initiatives amidst intra-ASEAN policy disagreements has to be acknowledged. ${ }^{75}$ Third, it is also necessary to remember that a security regime constitutes a narrow basis for promoting cooperation. As Jervis argued, although the Concert of Europe could be seen as a security regime, its norms of diplomatic restraint began to unravel with the fading of memories of the devastation resulting from the Napoleonic Wars. ${ }^{76}$ Interests that were compatible at one stage may drift apart with time. Within the context of ASEAN, such a narrow basis for long-term security cooperation is underlined by the weaknesses of democratic norms amongst ASEAN members. ${ }^{77}$ This in turn suggests that unexpected changes in government, such as coup d'états, may have the potential to replace political leaderships interested in cooperation with more adversarial leaderships with less interest in maintaining the security regime. ${ }^{78}$

In spite of these potential weaknesses, an ASEAN security regime offers a stronger prospect for promoting security cooperation against emerging non-traditional security concerns in Southeast Asia. Not only would an ASEAN security regime underline its members' common regional security interests, it also offers a basis, however gradual, for reinforcing regional norms in security cooperation. Moreover, by building on the existing traditional security regime between the founding members of ASEAN, such an approach has the potential to build on an already-functioning basis for cooperation. At the same time, however, in light of the likely limitations that would be faced in further enhancing security cooperation in Southeast Asia, an ASEAN security regime should not be seen as a panacea for addressing security concerns in Southeast Asia. ${ }^{79}$

\section{NOTES}

\footnotetext{
${ }^{1}$ Robert Jervis, “Security Regimes," International Organization, Vol. 36, No. 2, 1982, p. 357.

${ }^{2}$ Ibid.
} 
${ }^{3}$ Ibid.

${ }^{4}$ Ibid., p. 360.

${ }^{5}$ Ibid., pp. 359-362.

${ }^{6}$ Ken Booth and Nicholas Wheeler, The Security Dilemma: Fear, Cooperation and Trust in World Politics, Basingstoke: Macmillan, 2008, pp. 131-132.

${ }^{7}$ Charles Glaser, "Realists as Optimists: Cooperation as Self-Help," Security Studies, Vol. 5, No. 3, 1996, pp. 133-143.

${ }^{8}$ Charles Glaser, "Realists as Optimists," p. 142. See also Charles Glaser, "When Are Arms Races Dangerous? Rational versus Suboptimal Arming," International Security, Vol. 28, No. 4, 2004, pp. 52-53.

${ }^{9}$ Karl W. Deutsch, Sidney A. Burrell, Robert A. Kann, Maurice Lee Jr., Martin Lichterman, Raymond E. Lindgren, Francis L. Loewenheim and Richard W. Van Wagenen, Political Community and the North Atlantic Area: International Organization in the Light of Historical Experience, Princeton: Princeton University Press, 1957 and 1968, p. 6.

${ }^{10}$ Ibid.

${ }^{11}$ Jim Rolfe, "Regional Security for the Asia-Pacific: Ends and Means," Contemporary Southeast Asia, Vol. 30, No. 1, 2008, pp. 100-101.

${ }^{12}$ Robyn Lim, "The ASEAN Regional Forum: Building on Sand," Contemporary Southeast Asia, Vol. 20, No. 2, 1998, pp. 120-125.

13 "Asia Politics: Business as usual at ASEAN," The Economist, 4 March 2009.

${ }^{14}$ Chairman's Statement of the 14th ASEAN Summit, "ASEAN Charter for ASEAN Peoples, Cha-am, 28 February-1 March 2009," <http://www.aseansec.org/22389.htm>

15 “Asia Politics," 4 March 2009.

${ }^{16}$ Jurgen Haacke, "ASEAN and Political Change towards Myanmar: Towards a Regional Initiative?," Contemporary Southeast Asia, Vol. 30, No. 3, 2008, pp. 352-362.

${ }^{17}$ Alan Collins, Security and Southeast Asia, Singapore: Institute of Southeast Asian Studies )ISEAS), 2003, pp. 146-147.

${ }^{18}$ Charles Meconis and Michael D. Wallace, East Asian Naval Weapons Acquisitions in the 1990s: Causes, Consequences and Responses, Santa Barbara: Praeger, 2000, p. 189; Hideaki

Kaneda, "Southeast Asia's Widening Arms Race," <http://www.projectsyndicate.org/commentary/kaneda9>

${ }^{19}$ Hiro Katsumata, "Reconstruction of Diplomatic Norms in Southeast Asia: The Case for Strict Adherence to the "ASEAN Way," Contemporary Southeast Asia, Vol. 25, No. 1, 2003, p. 115.

${ }^{20}$ Rodolfo C. Severino, "ASEAN Beyond Forty: Towards Political and Economic Integration," Contemporary Southeast Asia, Vol. 29, No. 3, 2007, p. 408.

${ }^{21}$ Jerome Slater, "The Domino Theory and International Politics: The Case of Vietnam," Security Studies, Vol. 3, No. 2, 1993, pp. 186-190.

${ }^{22}$ Severino, "ASEAN Beyond Forty," p. 408.

${ }^{23}$ Hedley Bull, The Control of the Arms Race, London: Institute for Strategic Studies, 1967, p. 8 .

${ }^{24}$ Colin Gray, The Soviet-American Arms Race, Westmead: Saxon House, 1976, p. 4.

25 Allen S. Whiting, "East Asian Military Security Dynamics," $<$ http://www.ciaonet.org/wps/wha01/index.html>

${ }^{26}$ The Military Balance, 2005-06, London: International Institute of Strategic Studies, 2005, pp. 276-78; "CIA World Factbook," <https://www.cia.gov/library/publications/the-worldfactbook/geos/id.html> 
${ }^{27}$ International Institute of Strategic Studies, "Military Balance 2008 Press Statement, 5 February 2008," <http://www.iiss.org/publications/military-balance/the-military-balance2008/military-balance-2008-press-statement/>

${ }^{28}$ Malaysia has acquired F/A18s, MIG29s and SU-30s while Singapore has acquired F15s and F16s, see The Military Balance, 2005-2006, pp. 288-290, 296-298; and William Choong, “ Asia's arms race goes underwater," Straits Times, 9 April 2007.

${ }^{29}$ Soraya Jamal, "Scorpenes Not Expected to Start Regional Arms Race," Bernama News $\begin{array}{llll}\text { Agency, } & 13 & \text { November, } & \text { 2007, }\end{array}$ $<$ http://www.bernama.com/maritime/news.php?id=295768\&lang=en\&cat=ex>

${ }^{30}$ Richard Simpkin, Tank Warfare: An Analysis of Soviet and NATO Tank Philosophy, London: Brasseys Publishers, 1979, pp. 59.

${ }^{31}$ Ibid., pp. 54-57.

${ }^{32}$ The Military Balance, 2005-2006, pp. 296-298.

33 "Singapore Armed Forces new light tank (Singapore), Light tanks (under 25,000 kg)," Jane's Armour and Artillery, 6 April 2005.

${ }^{34}$ It is also notable that Singapore chose not to acquire the latest model of the Leopard II tank, the A6, but instead placed an order for the older A4 models.

${ }^{35}$ Glaser, "Realists as Optimists," pp. 133-143.

${ }^{36}$ Whiting, "East Asian Military Security Dynamics".

${ }^{37}$ See for instance, Ivan Simson, Singapore, Too Little, Too Late: The Failure of Malaya's Defences in 1942, Singapore: Asia Pacific Press, 1970, pp. 41-67.

${ }^{38}$ Whiting, "East Asian Military Security Dynamics"; Joon Num Mak, "International Cooperation in Regional Security: Non-Interference and ASEAN Arms Modernization," in Bjorn Moller (ed.), Security, Arms Control and Defence Restructuring in East Asia, Aldershot: Ashgate, 1998, p. 85.

${ }^{39}$ Carlyle A. Thayer, “The Five Power Defence Arrangements: The Quiet Achiever," Security Challenges, Vol. 3, No. 1, 2007, pp. 92-93.

40 “"Text of the Zone of Peace, Freedom and Neutrality Declaration, Malaysia, 27 November 1971," <http://www.aseansec.org/1215.htm>

41 "Treaty of Amity and Cooperation in Southeast Asia, Indonesia, 24 February 1976," $<$ http://www.aseansec.org/1217.htm>

42 "Treaty on the Southeast Asia Nuclear Weapon-Free Zone Bangkok, Thailand 15 December 1995," <http://www.aseansec.org/2082.htm>

43 "First ARF Chairman's Statement, July 1994," <http://www.aseanregionalforum.org/AboutUs/ARFObjectives/tabid/129/Default.aspx>

${ }^{44}$ Katsumata, "Reconstruction of Diplomatic Norms in Southeast Asia," p. 115.

${ }^{45}$ Dewi Fortuna Anwar, Indonesia in ASEAN: Foreign Policy and Regionalism, Singapore: ISEAS, 1994, pp. 169-171.

${ }^{46}$ Ibid., pp. 218-220, 226-228, 233-234.

${ }^{47}$ Ibid., pp. 167-180.

${ }^{48}$ Amitav Acharya, "Collective identity and conflict management in Southeast Asia," in Emanuel Adler and Michael Barnett (ed.), Security Communities, Cambridge: Cambridge University Press, 1998, pp. 199-200; Amitav Acharya, "Asean Needs New Tools for New Threats," The Straits Times, 4 June 2003. Admittedly, the admission of Cambodia, Laos, Myanmar and Vietnam brings an increased prospect of conflict in ASEAN; this will be addressed below.

${ }^{49}$ Lim, “The ASEAN Regional Forum,” pp. 117-118. 
50 "Troop build-up at hill-top temple," $B B C$ News, 17 July 2008 $<$ http://news.bbc.co.uk/2/hi/asia-pacific/7511417.stm>

${ }^{51}$ Ben Doherty, "Thailand steps up Thaksin Shinawatra extradition efforts," The Guardian, 10 November 2009.

52 Thomas Fuller, "Thailand Recalls Its Ambassador to Cambodia," New York Times, 5 November 2009.

${ }^{53}$ Anwar, Indonesia in ASEAN, pp. 157-159; Acharya, "Collective Identity and Conflict Management in Southeast Asia," p. 203.

${ }^{54}$ Lim, "The ASEAN Regional Forum,” pp. 123-125.

${ }^{55}$ Anwar, Indonesia in ASEAN, pp. 197-203.

${ }^{56}$ Acharya, "Collective Identity and Conflict Management in Southeast Asia," pp. 216-218.

${ }^{57}$ Sheldon Simon, "ASEAN and Multilateralism: The Long, Bumpy Road to Community," Contemporary Southeast Asia, Vol. 30, No. 2, 2008, p. 277.

${ }^{58}$ Barry Buzan, People, States and Fear: An Agenda for International Security Studies in the Post Cold War World, Boulder: Lynne Rienner, 1991, pp. 96-107.

${ }^{59}$ See for instance, Buzan, Ole Waever and Jaap de Wilder, Security: A New Framework for Analysis, Boulder: Lynne Rienner, 1998, pp. 75-80; Collins, Security and Southeast Asia, pp. 93-120.

${ }^{60}$ N. Ganesan, "Illegal Fishing and Illegal Migration in Thailand's Bilateral Relations with Malaysia and Myanmar," in Andrew T. H. Tan and J. D. Kenneth Boutin (eds.), NonTraditional Security Issues in Southeast Asia, Singapore: Select Publishing, 2001, pp. 510514.

${ }^{61}$ J. N. Mak, "Securitizing Piracy in Southeast Asia: Malaysia, the International Maritime Bureau and Singapore," in Mely Caballero-Anthony, Ralf Emmers and Amitav Acharya (eds.), Non-Traditional Security in Asia: Dilemmas in Securitisation, Aldershot: Ashgate, 2006, pp. 68-69.

${ }^{62}$ Buzan, et. al., Security: A New Framework for Analysis, pp. 123-126.

${ }^{63}$ Alan Dupont, The Environment and Security in Pacific Asia, Oxford: Oxford University Press, 1998, p. 75.

${ }^{64}$ Clark D. Neher, Southeast Asia in the New International Era, Boulder: Westview, 2002, p. 70 .

65 "ASEAN Regional Forum Inter-Sessional Support Group on Confidence Building Measures and Preventive Diplomacy," Singapore, 8-10 October 2008.

66 “ASEAN Charter for ASEAN Peoples," <http://www.aseansec.org/22389.htm>

67 "Cha-Am Hua Hin Declaration on the Intergovernmental Commission on Human Rights," Cha-am Hua Hin, Thailand, 23 October 2009," <http://www.asean.org/15thsummit/Declaration-AICHR.pdf>

${ }^{68}$ Barry Desker, "Is the ASEAN Charter Necessary?," Straits Times, 17 July 2009.

${ }^{69}$ Alan Collins, "A People-Oriented ASEAN: A Door Ajar or Closed for Civil Society Organizations?" Contemporary Southeast Asia, Vol. 30, No. 2, 2008, pp. 327-328.

${ }^{70}$ Katsumata, "Reconstruction of Diplomatic Norms in Southeast Asia," pp. 116-118.

${ }^{71}$ Oliver Hensengerth, "Transboundary River Cooperation and the Regional Public Good: The Case of the Mekong River," Contemporary Southeast Asia, Vol. 31, No. 2, 2009, pp. 331334.

${ }^{72}$ Hensengerth, "Transboundary River Cooperation,” pp. 334-340.

${ }^{73}$ Jervis, "Security Regimes," pp. 373-374.

${ }^{74}$ Haacke, "ASEAN and Political Change towards Myanmar," pp. 367-373. 


\footnotetext{
${ }^{75}$ Rolfe, "Regional Security for the Asia-Pacific," p. 105.

${ }^{76}$ Jervis, "Security Regimes," p. 368.

${ }^{77}$ Collins, Security and Southeast Asia, pp. 67-74.

${ }^{78}$ Dale Copeland, "The Constructivist Challenge to Structural Realism," International Security, No. 25, Vol. 2, 2000, p. 203.

${ }^{79}$ Rolfe, "Regional Security for the Asia-Pacific," pp. 114-115.
} 